\title{
Monitoring salinization processes in soils by using a chemical degradation indicator
}

\author{
M.J. Martínez-Sánchez ${ }^{\mathrm{a}}$, C. Pérez-Sirvent ${ }^{\mathrm{a}}$ *, J. Molina-Ruiz ${ }^{\mathrm{b}}$, M.L. Tudela ${ }^{\mathrm{b}}$, M.L. García-Lorenzo ${ }^{\mathrm{a}}$ \\ ${ }^{a}$ Department of Agricultural Chemistry, Geology and Pedology, Faculty of Chemistry, University of Murcia, Campus de Espinardo, Murcia, Spain \\ ${ }^{\mathrm{b}}$ Department of Physical Geography, Human Geography and Regional Geographical Analysis, Faculty of Geography, University of Murcia, Campus de La Merced, Murcia, Spain
}

\section{ABSTRACT}

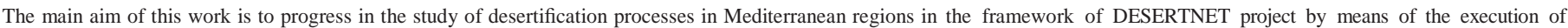

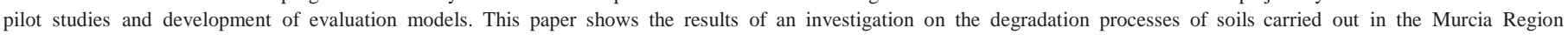

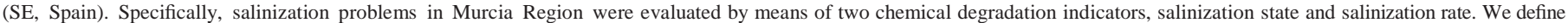

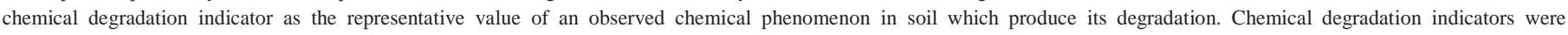

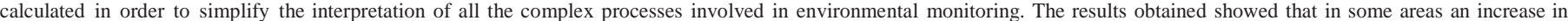
salinization processes is taking place. On the other hand, there are only a few points with high a risk of salinization, obtaining similar results in the two periods of time studied.

\section{Introduction}

According to the United Nations Convention in desertification, soil degradation could be defined as the reduction or loss of the biological or economic productivity and complexity of rain-fed cropland, irrigated cropland, or range, pasture, forest or woodlands resulting from natural processes, land uses or other human activities and habitation patterns such as land contamination, soil erosion and the destruction of the vegetation cover (UNCCD, 1994). In addition, desertification has been defined as land degradation in arid, semiarid and dry sub-humid areas resulting from various factors, including climatic variations and human activities(UNEP, 1994).

Soil salinization is mainly an arid zone problem leading to land desertification. It reduces soil quality, limits the growing of crops, constrains agricultural productivity, and in severe cases, leads to the abandonment of agricultural soils. The control of this problem involves inventorying, mapping, and monitoring soil salinity, which requires costeffective, rapid, and reliable methods for determining soil salinity in the field, and rapid, specific data-processing methods (Amezketa, 2006).

Much information exists on environmental problems, but it is easy to become overloaded with data. One way of simplifying the interpretation of all the complex processes involved in environmental monitoring is to use appropriate indicators. These indicators should provide information such as how, where and in which way the

\footnotetext{
* Corresponding author at: Department of Agricultural Chemistry, Geology and Pedology, Faculty of Chemistry, Campus de Espinardo, 30100, Murcia, Spain. Tel.: +34 868 887449; fax: +34868884148.

E-mail address: melita@um.es (C. Pérez-Sirvent).
}

processes associated to degradation occurs. Indicators can be easily communicated to the public or to policy-makers. In addition, they can be used as easy synthetic information in geographic information systems (GIS) to determine spatial extension and geographic distribution of degraded areas and to relate human actions (causes) to environmental conditions (effects).

\section{DESERTNET project}

The DESERTNET project is being managed in the framework of the Community Initiative Programme (CIP) Interreg III B-Western Mediterranean. This programme aims to achieve sustainable devel- opment of the territory, increase the competitiveness of its transport networks and communication systems and to valorise natural and cultural resources. The main aim of the DESERTNET project was to advance in the study of the desertification processes in the Mediterranean regions through carrying out pilot studies, exchanging experiences and developing models of evaluation.

The Region of Murcia (SE, Spain) has participated in this project since it is sensitive to suffering desertification processes due to its climatic characteristics and taking into account the intense agricul- tural use. The aim of this work was to progress in the study of desertification processes in Murcia Region by means of the execution of pilot studies and development of evaluation models. For such a purpose, the following partial objectives were carried out:

1. Collection of spatial-temporal data and elaboration of new basic data in order to propose indicators of chemical degradation.

2. To study the physicochemical nature of soils and its possible relationship with the processes due to natural and/or anthropic 
Table 1

Salinization indicator description.

\begin{tabular}{|c|c|c|c|}
\hline \multicolumn{2}{|c|}{ Salinization state } & \multicolumn{2}{|c|}{ Salinization rate } \\
\hline \multicolumn{2}{|c|}{ EC (dS/m) } & \multicolumn{2}{|l|}{$\Delta \mathrm{EC}$} \\
\hline b4 & Low & 0 & Negative \\
\hline $4-8$ & Moderate & $0-0.4$ & Light \\
\hline $8-16$ & High & $0.4-0.8$ & Moderate \\
\hline \multirow[t]{2}{*}{ N16 } & Very high & $0.8-1.6$ & Serious \\
\hline & & N1.6 & Very serious \\
\hline
\end{tabular}

causes, which could serve as a base for recovery plans or actions as well as good practices which could be integrated in agricultural and environmental policies.

\section{Selected areas for monitoring}

The Region of Murcia is located in the southeast of the Iberian Peninsula, with a surface of $11317 \mathrm{~km}^{2}$, and characterised by a semiarid climate. Average temperature is $18.5^{\circ} \mathrm{C}$ and precipitation ranges from 150 $\mathrm{mm}$ to $400 \mathrm{~mm}$, with an average value of $325 \mathrm{~mm}$.

The Region of Murcia belongs to the Betic domain. The Prebetic subdomain is represented in the north of Region of Murcia and is constituted by Mesozoic and Tertiary materials, affected by tangential tectonic processes. The Subbetic exists in the central part of the Region; their materials pertain to the Mesozoic and the Tertiary period and they have suffered intense compression processes. The internal zones are represented in the south and are constituted by Paleozoic and Triassic materials, which have suffered regional metamorphism and important tectonics processes. In the internal zones, Nevado- Filábride, Alpujárride and Maláguide complexes are representedinthe studied area. In addition, there are basins filled up with marine materials during Miocene and Pliocene. These basins contain sedi- mentary rocks, essentially marls, conglomerates and calcarenites. Finally, the area shows vestiges of postorogenic volcanic activity, in general with basic or intermediate composition.

The areas with a high agricultural activity in the Murcia Region are related to the areas close to the most important watercourses, Segura River and Guadalentin River (Pérez-Sirvent et al., 2003). In addition, these areas are also very important in the Campo de Cartagena zone. For this study, four areas were selected, being all of them affected by agricultural activities. These areas were: Upper Segura River Valley, Middle Segura River Valley, Campo de Cartagena and Guadalentin Valley. In the selected zones, the main land uses are represented, corresponding to 4 groups: drip irrigation, inundation irrigation, unirrigated soils and soils with natural vegetation, which correspond to abandoned agricultural areas.

\section{Materials and methods}

\subsection{Sampling sites and collected material}

The sampling sites corresponded to areas subjected to intense agricultural activity or soils with natural vegetation, which corre- spond to abandoned agricultural areas. Sampling sites were disposed in a $3 \mathrm{~km}$ square grid. Sampling points were obtained by a Global Positioning System (GPS).

Soil samples were collected from the surface soil $(0-25 \mathrm{~cm})$. Five subplots $(25 \times 25 \mathrm{~cm})$ for soil sampling were selected at the centre and on the diagonal lines of the plot $(1 \times 1 \mathrm{~m})$. Soil samples were collected with a shovel in each subplot, then mixed and homogenized and a subsample (about 2 kg) was taken (Pérez-Sirvent et al., 2009).

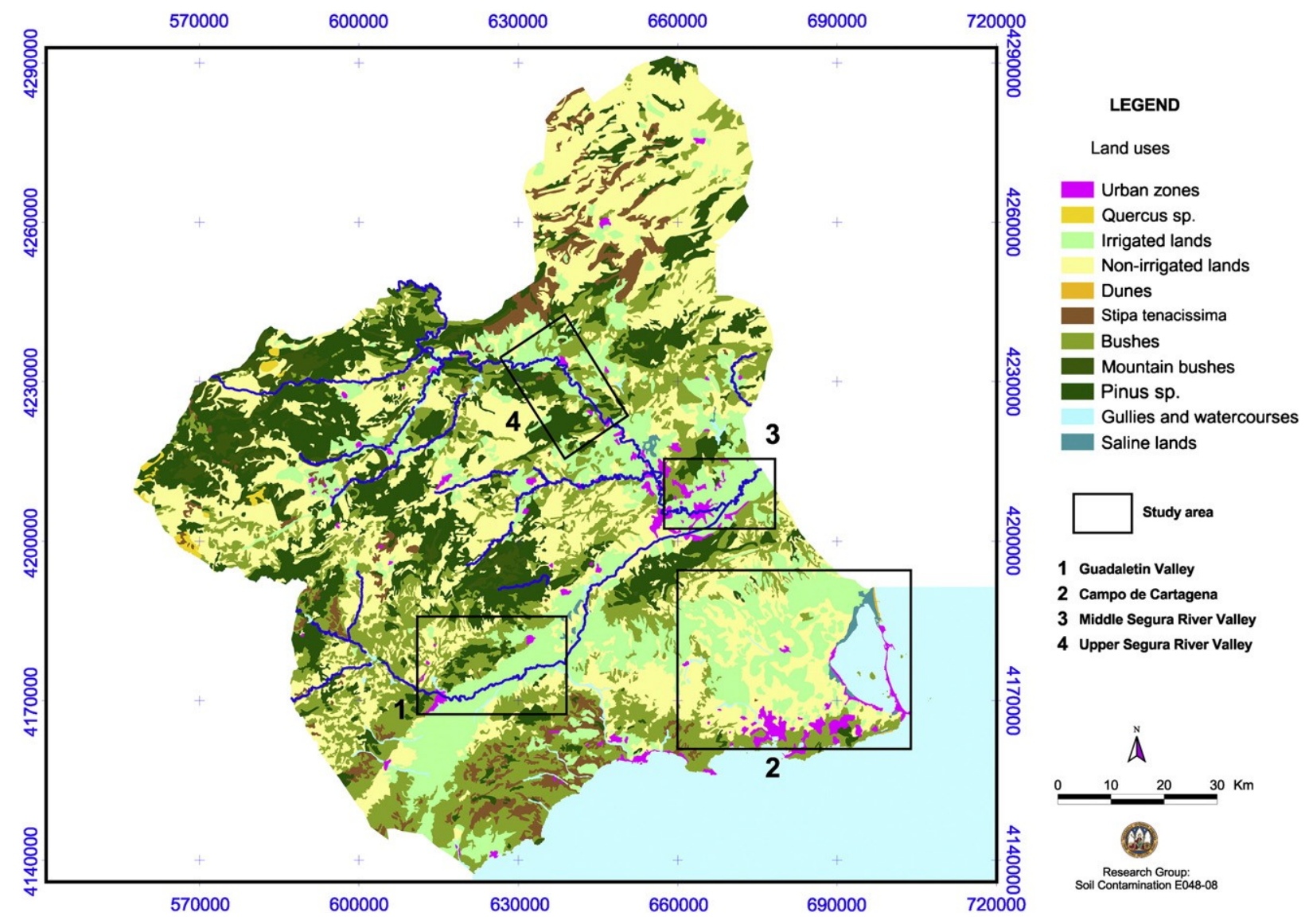




\subsection{Basic data determination}

Electrical conductivity (EC) (dS m ${ }^{-1}$ at $25^{\circ} \mathrm{C}$ ) was measured using a Crison GLP31 meter in the extracts obtained by filtering the 1:5 suspensions through a $0.45 \mu \mathrm{m}$ cellulose acetate disk filter. Sampling points were collected in two periods of time: the first one was in 1993, the data corresponding to samples collected in the framework of LUCDEME Project soil cartography (Alías et al., 1986a,b,c, 1987, 1988a, b, 1990a,b, 1992, 1993; CARM, 1999). On the other hand, results from 2006 were elaborated by the research group E048-08, Soil contam- ination, of the University of Murcia (MartínezSánchez et al., 2005). For both periods, soil samples were collected at the same location.

\subsection{Salinization indicator estimation}

Salinization is the process that leads to an excessive increase in the salinity of the soil due to agricultural practices, such that plant growth is inhibited (Saysel and Barlas, 2001). Soil salinity is a serious problem in arid and semiarid zones of the world where poor quality water is often the only available for irrigation (De Pascale et al., 2005). A high salt content could cause water assimilation problems in plants due to an osmotic pressure increase in soil solution. Moreover, high salt content could cause toxicity problems (Bastías et al., 2010; Li et al., 2010). Finally, a high salt content could disturb nutrition equilibrium by ion interactions.

The aim of this indicator is to study the spatial-temporal variation of the total soluble salt content in a soil sample by using its electrical conductivity value in the soil extract. In addition, this indicator shows a process which could have natural and/or anthropic causes (Martínez-Sánchez et al., 2005).

A salinization indicator was determined from basic data, trans- forming them into a numeric code which allows their integration in numerical models and an automated treatment, compatible with GIS.

- Salinization state: This indicator was calculated by using the electrical conductivity results $\left(\mathrm{dS} \mathrm{m}^{-1}\right)$ in the soil saturation extract for each soil sample. After EC was determined, results were reclassified in 4 intervals for mapping (Table 1).
Table 2

Percentiles 25, 50, 75 and 95 for EC in the studied area.

\begin{tabular}{lrrrrrrrr}
\hline & \multicolumn{1}{c}{1993} & \multicolumn{1}{c}{2006} \\
\cline { 2 - 9 } & p25 & p50 & p75 & p95 & p25 & p50 & p75 & p95 \\
\hline Guadalentin Valley & 0.86 & 1.67 & 3.59 & 14.76 & 1.38 & 3.00 & 5.67 & 17.63 \\
Campo de Cartagena & 0.58 & 0.95 & 1.89 & 6.20 & 0.72 & 1.73 & 3.72 & 8.20 \\
Middle Segura River Valley & 1.80 & 3.70 & 4.10 & 4.91 & 3.59 & 4.31 & 6.00 & 8.25 \\
Upper Segura River Valley & 2.88 & 3.23 & 3.81 & 3.98 & 1.23 & 3.05 & 3.54 & 6.41 \\
\hline
\end{tabular}

- Salinization rate: This indicator was defined as the electrical conductivity temporal variation in the soil saturation extract for each soil sample. This indicator was calculated comparing the salinization state in two periods of time, thus providing a measure of the temporal evolution of the salinization degradation of soils (FAO- PNUMA, 1984). To determine the salinization rate indicator, electrical conductivity values were employed, obtaining the varia- tions between sampling periods and next dividing them between the years elapsed between sampling periods. After the electrical conductivity increase/decrease was determined, the results were reclassified in 5 intervals for GIS representation (Table 1).

\subsection{Geographic Information System (GIS) methodology}

GIS methodology allows representing indicators in the studied area. Mapping a variable usually requires an intensive sampling with a considerable amount of data, to exhaustively show the spatial patterns of soils. However, the sample size of observation may be restricted by the soil sampling plan and the level of chemical measurements. In order to reduce the cost of sampling and measurements for mapping, a spatial interpolation technique, kriging, is increasingly being used in contaminated sites. Kriging could be used with observed data to estimate the element concentration at unsampled locations (Juang et al., 2005). Ordinary kriging is a form of weighted local spatial interpolation that uses a Gaussian model to derive spatial variables supported by a data-set for the area being analyzed (Cook et al., 2008).

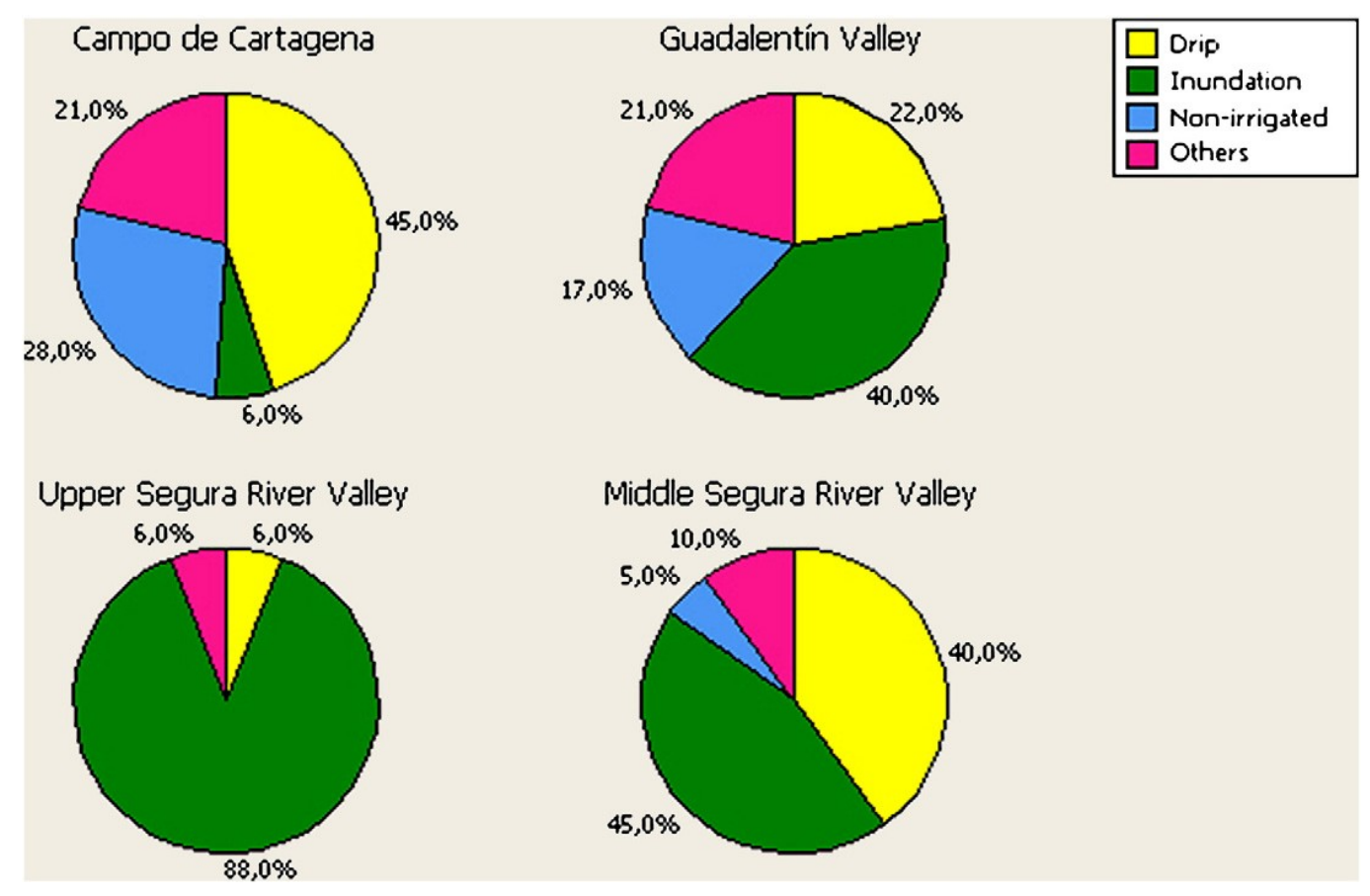




$$
\frac{I_{1 . \ldots}}{I_{1}}
$$


The sampling points, obtained by GPS, were integrated to create a database in which the coordinates and the value of the analytical characteristics for each point were included. Geostatistical analysis consisting of kriging and mapping was performed using the geostatistical analyst extension of ArcGIS 8.3 software. For mapping, obtained results were reclassified as a function of the intervals considered (Table 1).

\section{Results and discussion}

\subsection{Soils and land uses}

In Guadalentin Valley predominant soils are Fluvisols, located close to Guadalentin Valley. In addition, calcic and petrocalcic Xerosols and Regosols were found in this area. In Campo de Cartagena predominant soils are calcic and petrocalcic Xerosols, followed by Litosols in the south and southwest, corresponding to a mining site. Moreover, and in a lesser content, Regosols are also present in this zone, corresponding to hillsides of precoastline mountains.

Middle Segura River Valley soils are mainly Fluvisols, located around the Segura River watercourse. Fluvisols are surrounded by calcic Xerosols and Regosols in the margin northwest and southeast of the study zone. Litosols in this area are located in high elevation points. Finally, the Upper Segura River Valley is mainly formed by Fluvisols, located around the Segura River watercourse. The north of this area is composed by calcic Regosols and in the south, and following the Segura watercourse, Litosols are predominant, being some of them in a saline phase. Lastly, the south of this area is mainly composed by Regosols.
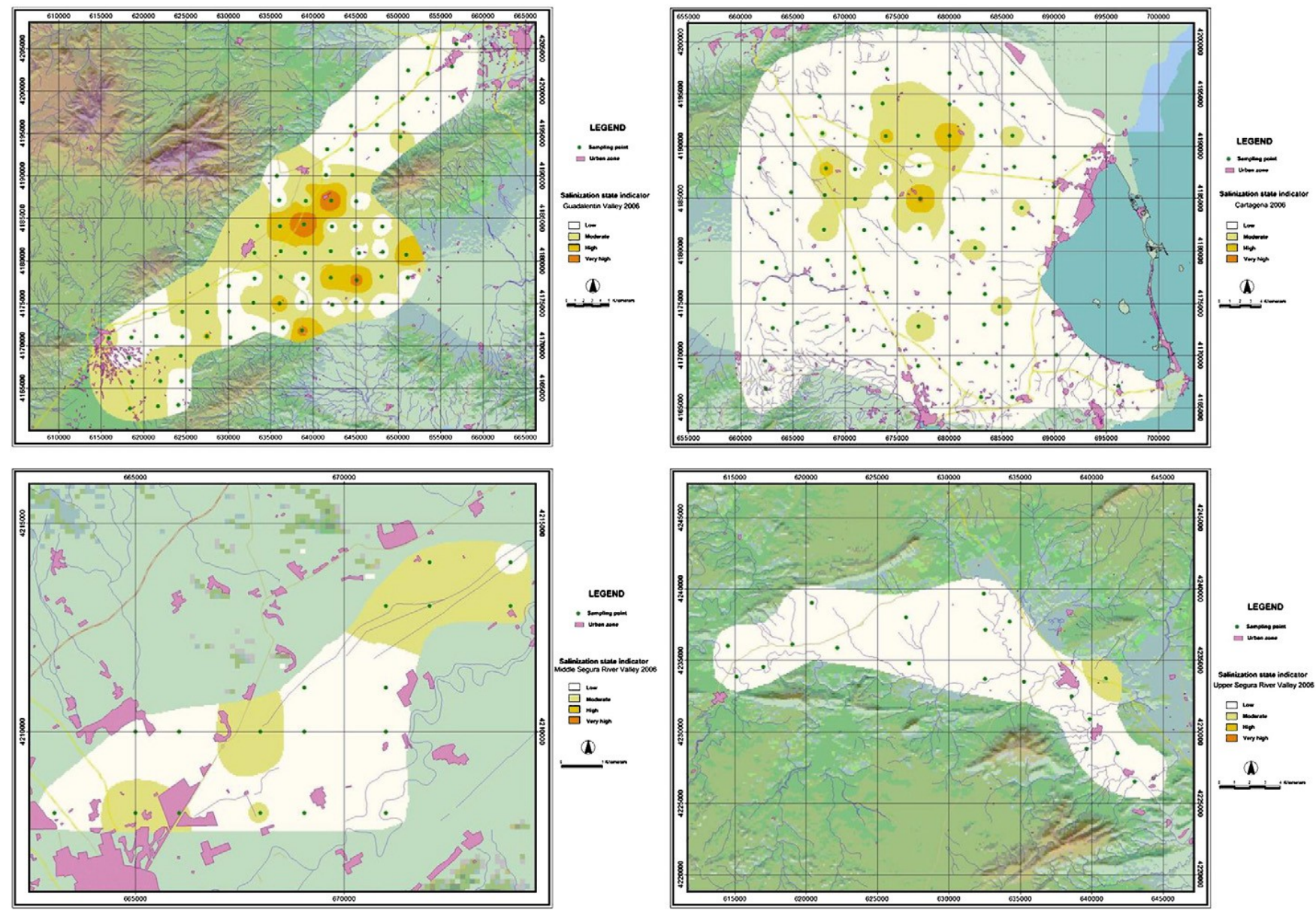

Fig. 1 shows an actual vegetation map in Murcia Region and Fig. 2 summarises agricultural uses in each area. Guadalentin Valley is mainly composed by highly productive soils, where historical irrigable crops coexist with modern intensive crops. There are salinization problems due to natural origin but increased by human activities. In addition, there are natural soils with bushes and Pinus sp. (Fig. 1). In this area the most represented land use is inundation irrigation, followed by drip irrigation and non-irrigated crops (Fig. 2).

Campo de Cartagena is also dedicated to agricultural activities, with irrigated and non-irrigated crops (Fig. 1). About $45 \%$ of collected samples corresponded to drip irrigation, non-irrigated crops and inundation irrigation being less frequent (Fig. 2).

The Middle Segura River Valley actual vegetation is characterized by irrigated crops and urban zones. In addition, some areas with bushes are present. However, in the Upper Segura River Valley, pine forest and bushes are predominant (Fig. 1). Soils with agricultural activities are irrigated by inundation, being more important in the Upper Segura River Valley, followed by drip-irrigated crops (Fig. 2).

For all the studied area, fluvisols generally correspond to zones with irrigated crops, by inundation or drip irrigation. On the other hand, for xerosols non-irrigated and irrigated crops coexist, and Regosols show natural vegetation or abandoned crops.

\subsection{Chemical analysis}

Table 2 shows percentile values for electrical conductivity results in the studied areas for both sampling dates of time. For both, the highest values were found in Middle Segura and Upper Segura River Valley. Although the highestp50 values were found in these areas, the 


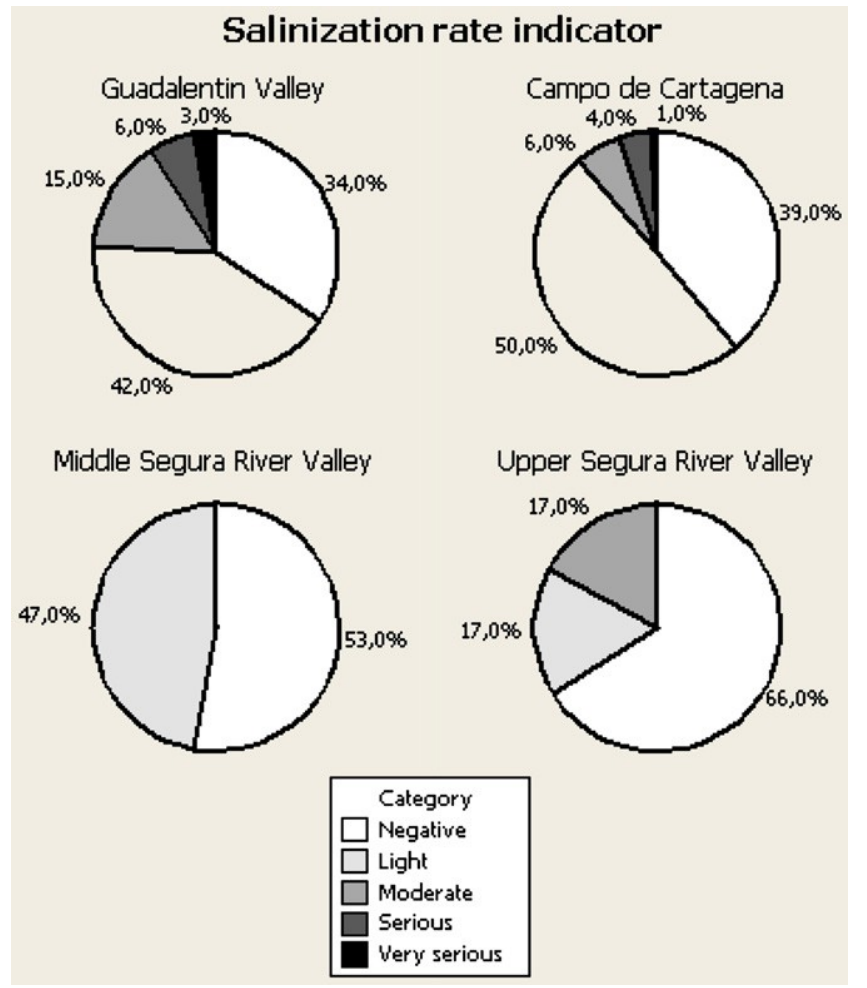

Fig. 6. Percentage of sampling points included in each salinization rate indicator interval for all the studied areas.
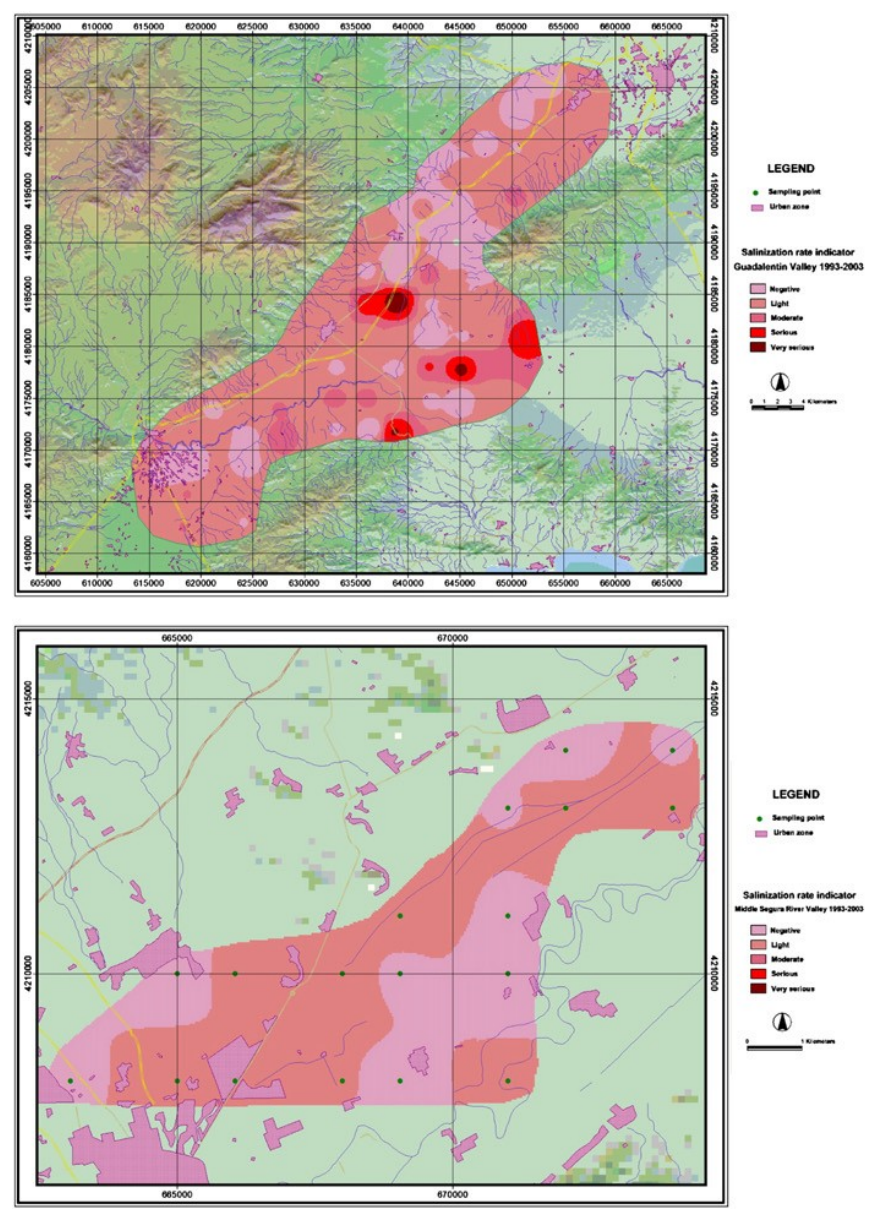

highest extreme values (p95) were found in Guadalentin Valley for both sampling dates.

\subsection{Salinization indicator}

Fig. 3 shows the percentage of sampling points included in each interval of the salinization state indicator for the two sampling dates considered for this work (1993 and 2006).

In 1993, the highest salinization indicator state was found in the Guadalentin Valley, followed by the Upper Segura River Valley and the Middle Segura River Valley. Campo de Cartagena showed a low salinization state, only a few points were included as affected by high or very high salinization. The results of salinization state indicator were graphically represented, and mapping results are shown in Fig. 4.

In 2006, the highest increase for this indicator was found in the Guadalentin Valley area, followed by the Middle Segura River Valley, However, in the Upper Segura River Valley, the salinization value decreased. In Campo de Cartagena, the percentage of soils affected by moderate salinization was higher than in 1993. The results of salinization state indicator were graphically represented, and map- ping results are shown in Fig. 5.

The results for the salinization rate indicator (Fig. 6) showed that only in a few points the salinization state did not change from 1993 to 2006. Guadalentin Valley and Campo de Cartagena showed the highest values for this indicator, being some points affected by a serious or very serious salinization risk. In the Middle Segura River Valley, almost 50\% of the sampling points showed a slight increase in the indicator, whereas the other $50 \%$ showed a light salinization risk.

Fig. 7. Salinization rate indicator in the studied areas in the period 1993-2006. 
Finally, the Upper Segura River Valley showed a large proportion of points where the salinization decreased, the risk being in other cases light or moderate (Fig. 6). The results of the salinization rate indicator are shown in Fig. 7.

\section{Conclusions}

The use of the salinization indicator allows degradation processes in a spatio-temporal perspective to be detected. Generally, chemical degradation indicators are an efficient tool for land use planning, because they provide information such as how, where and in which way the processes associated to degradation occur. In addition, they permit to obtain an overall view, allowing to determine stressing factors, variables which reveals critical points and possible remedi- ation/palliative actions. For such purpose, it is necessary to have methodological tools which allow to collect, analyse and standardise large amounts of environmental and social information.

In the studied area, the electrical conductivity values in most of the sampling points corresponding to the first sampling date in Guadalentin Valley, Middle Segura River Valley and Campo de Cartagena presented values lower than in the 2006 period, that is, a gradual salinization process is taking place, due to the poor quality of the irrigation water. However, in the Upper Segura River Valley electrical conductivity values in 1993 were higher than those determined in 2006, thus indicating that the salinization process in this area has been controlled.

\section{Acknowledgement}

The authors are grateful to the Spanish Ministerio de Ciencia e Innovación (CTM2008-04567) for financial support.

\section{References}

Alías, L.J., Ortiz, R., Hernández, J., Fernández, M.T., Linares, P., Martínez, J., Alcaraz, F., 1986a. Proyecto LUCDEME. Map of soils 1:100000. Cieza-891. Ministerio de Agricultura, Pesca Alimentación. ICONA- Universidad de Murcia.

Alías, L.J., Ortiz, R., Hernández, J., Martínez, J., Alcaraz, F., López, B., 1986b. Proyecto LUCDEME. Map of soils 1:100000. Mula-912. Ministerio de Agricultura, Pesca y Alimentación. ICONA- Universidad de Murcia.

Alías, L.J., Ortiz, R., Hernández, J., Martínez, J., Alcaraz, F., López, B., 1986c. Proyecto LUCDEME. Map of soils 1:100000. Calasparra-890. Ministerio de Agricultura, Pesca y Alimentación. ICONA- Universidad de Murcia.

Alías, L.J., Ortiz, R., Martínez, J., Alcaraz, F., López, B., 1987. Proyecto LUCDEME. Map of soils 1:100000. Coy-932. Ministerio de Agricultura, Pesca y Alimentación. ICONA- Universidad de Murcia.

Alías, L.J., Ortiz, R., Hernández, J., Martínez, J., Alcaraz, F., López, B., 1988a. Proyecto LUCDEME. Map of soils 1:100000. Puerto Lumbreras-975. Ministerio de Agricul- tura, Pesca y Alimentación. ICONA- Universidad de Murcia.
Alías, L.J., Ortiz, R., Hernández, J., Martínez, J., Linares, P., Alcaraz, F., Marín, P., Cámara, P., 1988b. Proyecto LUCDEME. Map of soils 1:100000. Lorca-953. Ministerio de Agricultura, Pesca y Alimentación. ICONA- Universidad de Murcia.

Alías, L.J., Ortiz, R., Martínez, J., Linares, P., Alcaraz, F., Marín, P., 1990a. Proyecto LUCDEME. Map of soils 1:100000. Zarcilla de Ramos-931. Ministerio de Agricultura, Pesca y Alimentación. ICONA- Universidad de Murcia.

Alías, L.J., Ortiz, R., Martínez, J., Linares, P., Alcaraz, F., Marín, P., 1990b. Proyecto LUCDEME. Map of soils 1:100000. Alcantarilla-933. Ministerio de Agricultura, Pesca y Alimentación. ICONA- Universidad de Murcia.

Alías, L.J., Ortiz, R., Martínez, J., Linares, P., Alcaraz, F., Marín, P., Sánchez-Navarro, A., 1992. Proyecto LUCDEME. Map of soils 1:100000. Sotana-954. Ministerio de Agricultura, Pesca y Alimentación. ICONA- Universidad de Murcia.

Alías, L.J., Ortiz, R., Martínez, J., Linares, P., Alcaraz, F., Marín, P., Sánchez-Navarro, A., 1993. Proyecto LUCDEME. Map of soils 1:100000. Moratalla-889. Ministerio de Agricultura, Pesca y Alimentación. ICONA- Universidad de Murcia.

Amezketa, E., 2006. An integrated methodology for assessing soil salinization, a pre- condition for land desertification. Journal of Arid Environments 67, 594-606.

Bastías, E., Alcaraz-López, C., Bonilla, I., Martínez-Ballesta, M., Bolaños, L., Carvajal, M., 2010. Interactions between salinity and boron toxicity in tomato plants involve apoplastic calcium. Journal of Plant Physiology 167, 54-60.

CARM (Autonomous Community of the Region of Murcia), 1999. Mapa Digital de Suelos de la Región de Murcia. Consejería de Agricultura, Agua y Medio Ambiente, Región de Murcia.

Cook, S.E., Jarvis, A., Gonzalez, J.P., 2008. A new global demand for digital soil information. In: Hartemink, A.E., McBratney, A., Mendonça-Santos, M.L. (Eds.), Digital soil mapping with limited data. Springer.

De Pascale, S., Maggio, A., Barbieri, G., 2005. Soil salinization growth, yield and mineral composition of cauliflower and broccoli. European Journal of Agronomy 23, 254-264.

FAO-PNUMA. Food and Agriculture Organization of the United Nations, 1984. Directrices para la evaluación y la representación cartográfica de la desertificación. Roma, Italia.

Juang, K.W., Lee, D.Y., Teng, Y.T., 2005. Adaptive sampling based on the cumulative distribution function of order statistics to delineate heavy-metal contaminated soils using kriging. Environmental Pollution 138 (2), 268-277.

Li, Q., Cai, S., Mo, C., Chu, B., Peng, L., Yang, F., 2010. Toxic effects of heavy metals and their accumulation in vegetables grown in a saline soil. Ecotoxicology and Environmental Safety 73, 84-88.

Martínez-Sánchez, M.J., Pérez-Sirvent, C., Tudela, M.L., Molina, J., Linares, P., Navarro Hervás, M.C., Vidal, J., Barberán, R., Mantilla, W., Tovar, P., Solano, A., Marimón, J., Agudo, I., Hernández, C., 2005. Desertificación: Monitorización mediante indica- dores de degradación química Proyecto DESERTNET: Acción piloto Región de Murcia. Consejería de Medio Ambiente y Ordenación del territorio, Dirección General del Medio Natural, Murcia

Pérez-Sirvent, C., Martínez-Sánchez, M.J., Vidal, J., Sánchez, A., 2003. The role of low- quality irrigation water in the desertification of semi-arid zones in Murcia, SE Spain. Geoderma 113, 109-125.

Pérez-Sirvent, C., Martínez-Sánchez, M.J., García-Lorenzo, M.L., Molina, J., Tudela, M.L., 2009. Geochemical background levels of zinc, cadmium and mercury in anthro- pically influenced soils located in a semi-arid zone (SE, Spain). Geoderma 148, 307-317.

Saysel, A.K., Barlas, Y., 2001. A dynamic model of salinization on irrigated lands. Ecological Modelling 139, 177-199.

UNCCD, (United Nations Convention to Combat Desertification), 1994. http://www. unccd.int/convention/text/convention.php\#begin1994.

UNEP, (United Nations Environment Programme), 1994. United Nations Convention to Combat Desertification in those countries experiencing serious drought and/or desertification, particularly in Africa. Text with annexes United Nations Environ- ment Programme for the Convention to Combat Desertification (CCD), Interim Secretariat for theCCD, Geneva. 